\title{
Geochemical Evaluation of Thermal Maturity of the Cretaceous Sediments in the Calabar Flank based on the Distribution of the Polynuclear Aromatic Hydrocarbons
}

\author{
Anietie E. Ekot ${ }^{1}$, C. J. Igwuagwu ${ }^{2}$, Sam O. Onyekuru $^{3}$, Clement E. Bassey ${ }^{4}$ \\ ${ }^{1,4}$ (Faculty of Natural and Applied Sciences, Akwa Ibom State University, Ikot Akpaden,P.M.B.1167,Uyo,Akwa \\ Ibom State, Nigeria) \\ ${ }^{2,3}$ (Department of Geosciences, Federal University of Technology, Owerri, Imo State, Nigeria)
}

\begin{abstract}
The thermal maturity parameter used in the evaluation of the hydrocarbon generative potential of the sedimentary organic matter is based largely on the extent of molecular transformation of the biological markers due to geothermal stress which is a function of depth or burial history. In particular the transformations leading to the formation of Polynuclear Aromatics usually occur at the end of diagenesis up to the onset of catagenesis. . An in-depth study of the transformation leading to the formation of polynuclear aromatic steroidal hydrocarbons revealed a step by step thermally mediated aromatization of the non-aromatic biogenic species during diagenetic/catagenetic evolution of organic matter in an anoxic environment. Since the formation of $P A H s$ is a heat mediated process which increases with depth, then its concentration or the amount per unit mass of the rock sample can be used to estimate the thermal maturity of organic matter in the sediment .In light of the above, this work has evaluated the distribution profile of the PAHs in the Cretaceous sediments of the Calabar Flank using Gas Chromatograph interfaced to a Mass Spectrometer (GC-MS), an analytical tool combination widely used in the study of petroleum geochemistry. The results of the study based on the most dominant polynucear aromatic species namely, anthracene and phenanthrene revealed that Nkporo Shale(NS)samples from various locations in the Basin had a average PAH of $0.05 \mathrm{mg} / \mathrm{Kg}$ (anthracene) and $0.06 \mathrm{mg} / \mathrm{Kg}$ (phenanthrene). While the PAH value of Ekenkpon Shale(ES) samples was on the average $0.01 \mathrm{mg} / \mathrm{Kg}$ and $0.02 \mathrm{mg} / \mathrm{Kg}$ for anthracene and phenanthrene respectively. New Netim Marl(NNM) however gave the PAH value of only $0.001 \mathrm{mg} / \mathrm{Kg}$ for phenanthrene and nil for anthracene. On the other hand Awi Sandstone (AS), Mfamosing Limestone (ML) and Nkporo Mudstone(NM) all fell within the non-detectable range. Based on the foregoing, PAH values can be used to evaluate the maturation level of organic matter in the sediments.
\end{abstract}

Keywords: Cretaceous Sediments, Polynuclear Aromatic Hydrocarbons, Thermal Maturity, Distribution Profile

\section{Introduction}

The name Calabar Flank was first coined by [1] for the part of the continental margin of Nigeria characterized by block faults with NW-SE trending hoist and graben structures such as Ituk high and the Ikang trough. Thus the Calabar Flank with a total thickness of over $3,500 \mathrm{~m}$ is related to the South Atlantic Cretaceous marginal basins which are characterized by similar horst structures[2].The exposed Cretaceous sediments of the basin which is the major focus of this work appear rather unique in that the entire Upper Cretaceous sequence is exposed within a narrow stripe measuring about $8 \mathrm{Km}$ (Fig 1b). A great deal of work has been carried out in this marginal sedimentary basin since the last three to four decades and these include works on biostratigraphy, depositional environment and diagenesis of Albian carbonate by[3]; the sedimentology of the Cretaceous sediments by [4]; petroleum source rock assessment of Nkporo shale [5], as well as Upper Cretaceous assemblage from Nkporo Shale by [6] to mention but a few. The present work is aimed examining the distribution of Polynuclear Aromatic Hydrocarbons (PAHs) and the use of PAH concentration as a parameter to evaluate thermal maturity and by extension the hydrocarbon generative potentials of the sediments in the marginal basin. This work is driven by the need to expand the frontier of search for hydrocarbon in the area because other geological provinces such as marginal basins of Equitorial Guinea, Angola and Gabon all in Africa, that show striking similarities in terms of stratigraphy and geological setting with the Calabar Flank are prolific oil fields.But despite long years of search no commercial accumulation of hydrocarbons has so far been discovered in the Calabar Flank. It is hoped that the data obtained in this study will further boost the research efforts in studying the sedimentary geochemistry of the Calabar Flank with the ultimate goal of ascertaining its hydrocarbon generative potentials, both in short and long terms. 


\subsection{Geological Setting and Stratigraphy}

The geological expression known as the Calabar Flank was first described by [1] and later by [7] as an epirogenic basin situated in the easternmost part of the sedimentary basin in southern Nigeria. The Calabar Flank is part of the continental margin of Nigeria dominated by block faults with NW-SE trending horst and graben such as Ituk and the Ikank trough. The basin which lies on Lat. $5^{\circ} 00^{\prime} \mathrm{N}$ and between Long. $8^{\circ} 00^{\prime}$ and $8^{\circ} 30^{\prime} \mathrm{E}$ (Fig. 1a) contains about four thousand metres of Albian to Maastrichtian sediments in outcrop section[8] and is bounded in the north by the basement rock of Albian Oban Massif; in the south by the Niger Delta hinge line; in the east by the Cameroun volcanic line and in the west by Ikpe platform. [9] suggested a rift origin of the Calabar Flank while[10] sees the basin formation as a response to a slight adjustment in the shape of Africa during its crustal plate separation from South America coupled with the eustatic changes in the sea level within the South Atlantic. Hence its description by[11] as a distinct geologic province with peculiar tectonic style and attendant stratigraphic evolution. The Cretaceous sediment of the Calabar Flank is made up of the Upper and Lower segments. The Upper sediments range from dark gray to bluish shale with mudstone intercalation (Nkporo shale) to thick black shales with mudstone, sandstone and occasional limestone intercalations. While the sediments in the Lower segment are largely flaggy(fissile) limestone with admixture of ferruginized and conglomeratic sequence of Awi Formation. The stratigraphic succession in the Calabar Flank is mostly of Cretaceous age comprising a basal Neocomian-Aptian syn-rift fluvial sandstone,. the Awi formation and the marine syn-rift Odukpani group of Albian and Late Cretaceous age. The Odukpani Group [12] comprises the Middle Albian Mfamosing limestone, the Late Albian Ekenkpon shale and the Conician New Netim Marl.

Sedimentation in this marginal basin began with the initial deposition of fluvio-deltaic cross-bedded sands of Awi formation [13] in early Cretaceous times (probably Aptian). This lithologic unit overlies the Precambian basement complex of Oban Massif. The Awi formation (non-fossiliferous arkosic sandstone), is in turn overlain by a relatively stable carbonate platform, namely Mfamosing Formation, a limestone formation that is partly exposed along the pre-cambian basal complex of Oban Massif as a result of diatropism (probably an epeirogenic uplift) associated with the Neogene tectonics along the Cameroun volcanic line [2].Thus the Limestone deposits emerged as a result of the first marine incursion in the Middle Albian after which the faulted blocks allow widespread deposition sequence of shales with very minor calcareous (marl) intercalations alternated by the deposition of thin dark shale beds of dominantly shale lithology with occasional mudstone [8]. The lithogic unit immediately overlying this carbonate platform is a thick black and highly fissile shales with minor but frequent intercalation of marls and calcareous mudstone known as Ekenkpon shale formation, believed to be a product of two transgressive cycles that took place during the late Albian-Cenomenian and early Turonian. Ekenkpon (brownish grey/dark grey flaggy shales with mudstone intercalations) formation underlies the New Netim Marl (marlstone with occasional shale intercalations), which together form part of the Odukpani Group, a Late Cretaceous post-rift marine unit[2]. The Awi Formation and the Odukpani Group were deposited before the Santonian compressional tectonic phase [14]; while the Campanian-Maastrichtian Nkporo Shale (bluish black carbonaceous shale with mudstone intercalations), the youngest lithologic unit of the Cretaceous sediments in the stratigraphic succession of the Calabar Flank overlies the New Netim Marl. The sedimentary successions in the Calabar Flank by various workers are presented in (Tables 1-2), with Awi Formation as the oldest at the base and Nkporo shale whose outcrop section remains the youngest lithologic unit of the Cretaceous is at the top [6].

\subsection{Sample Collection}

\section{Methodology}

A total of seventeen surface (outcrop) samples of the Cretaceous sediments were picked at various locations where they outcrop (Fig $1 \mathrm{~b}$ ) across the length and breadth of the basin, using appropriate tools and instruments such as hammer and GPS. The outcrop samples were collected and coded as CF- $\mathrm{L}_{\mathrm{n}} \mathrm{X}$, where CF is the acronym for the Calabar Flank; $L_{n}$, the location serial number and $X$, to differentiate one sample from another in a particular location. The sediment samples were Awi Sandstone, Mfamosing Limestone, Ekenkpon Shales, New Netim Marl, Nkporo Shale and Nkporo Mudstone.

\subsection{Sample Preparation}

The outcrop samples were initially cleaned by seeping in $100 \%$ dichloromethane with shaking followed by decanting of the solvent until the rocks were clean. After drying, the samples were washed under running tap water and then dried again in an oven at a pre-set temperature of $30^{\circ} \mathrm{C}$. About $200 \mathrm{mg}$ of the pre-cleaned shale was crushed and accurately weighed into clean LECO crucibles. The rocks were then de-mineralized with hot $10 \% \mathrm{HCl}$ and afterwards washed repeatedly with distilled water, dried at $60^{\circ} \mathrm{C}$, pulverized and preserved. 


\subsection{GC-MC Analysis}

The samples were analysed for the concentration of Polynuclear Aromatic Hydrocarbons(PAHs) using Agilent 7890 Gas Chromatograph interfaced to a HP5970 Mass Spectrometer and operated at 70 $\mathrm{V}$ in impact and selected ion monitoring modes equipped with electron multiplier defector. The gas chromatograms for the representative samples are shown in (Figs 2ato2c).

\section{Results and Discussions}

The work which focussed on the distribution of polynuclear aromatic hydrocarbons in the Cretaceous sediments of the Calabar Flank Southeastern Nigeria, has been carried out. The results of the GC-MS analysis of the three sediment samples with detectable concentration of Polynuclear Aromatic Hydrocarbons (PAHs) are presented in Figures 2a,2b and 2c. The representative mass chromatogram (Fig.2a) of Ekenkpon Shales represented by sample CF-L1B indicates that the sediment is rich in vast array of aromatic hydrocarbons such as naphthalene, pyrene, benzo(b)fluoranthene, benzo(k)fluoranthene, benzo(a)pyrene, phenanthrene and anthracene, with the last two in the series as the most abundant polynuclear aromatic species in the sediment.

In contrast the GC-MS analysis (Fig.2b) for the New Netim Marl samples represented by CF-L6B shows phenanthrene as the only polynuclear aromatic species in the sediment. The absence of other polynuclear aromatic species in New Netim Marl indicates that there was low biogenic input rich in polycyclic alkanes during diagenesis. In other words the condition under which sedimentation occurred may not have favoured the preservation of biogenic input rich in polycycloalkanes.

The third Cretaceous sediment sample of interest in the the Calabar Fank is the Nkporo Shales represented by sample CF-L7A. Like the results of the Ekenkpon samples the GC-MS analysis (Fig.2c) of Nkporo Shales depicts the sediments as being rich in a wide spectrum of polynuclear aromatic hydrocarbons such as anthracene, phenanthrene, anthracene, pyrene, benzo(a)pyrene ,benzo(a)anthracene, benzo(b) fluoranthene, benzo(k)fuorenthene with the first two polynuclear aromatic hydrocarbons in the series as the most dominant species.. The results based on the most dominant polynucear aromatic species namely, anthracene and phenanthrene indicate that Nkporo Shale (NS) samples from various locations across the basin are the richest in polynuclear aromatic hydrocarbons with an average $\mathrm{PAH}$ of $0.05 \mathrm{mg} / \mathrm{Kg}$ (anthracene) and $0.06 \mathrm{mg} / \mathrm{Kg}$ (phenanthrene). While the PAH value of Ekenkpon Shale(ES) samples gave an average concentration of polynuclear aromatic hydrocarbons of $0.01 \mathrm{mg} / \mathrm{Kg}$ and $0.02 \mathrm{mg} / \mathrm{Kg}$ for anthracene and phenanthrene respectively. New Netim Marl(NNM) however gave the PAH value of only $0.001 \mathrm{mg} / \mathrm{Kg}$ for phenanthrene and nil for anthracene. On the other hand Awi Sandstone(AS), Mfamosing Limestone(ML), Nkporo Mudstone(NM) all fell within the non-detectable range.

\section{List of Figures and Tables}

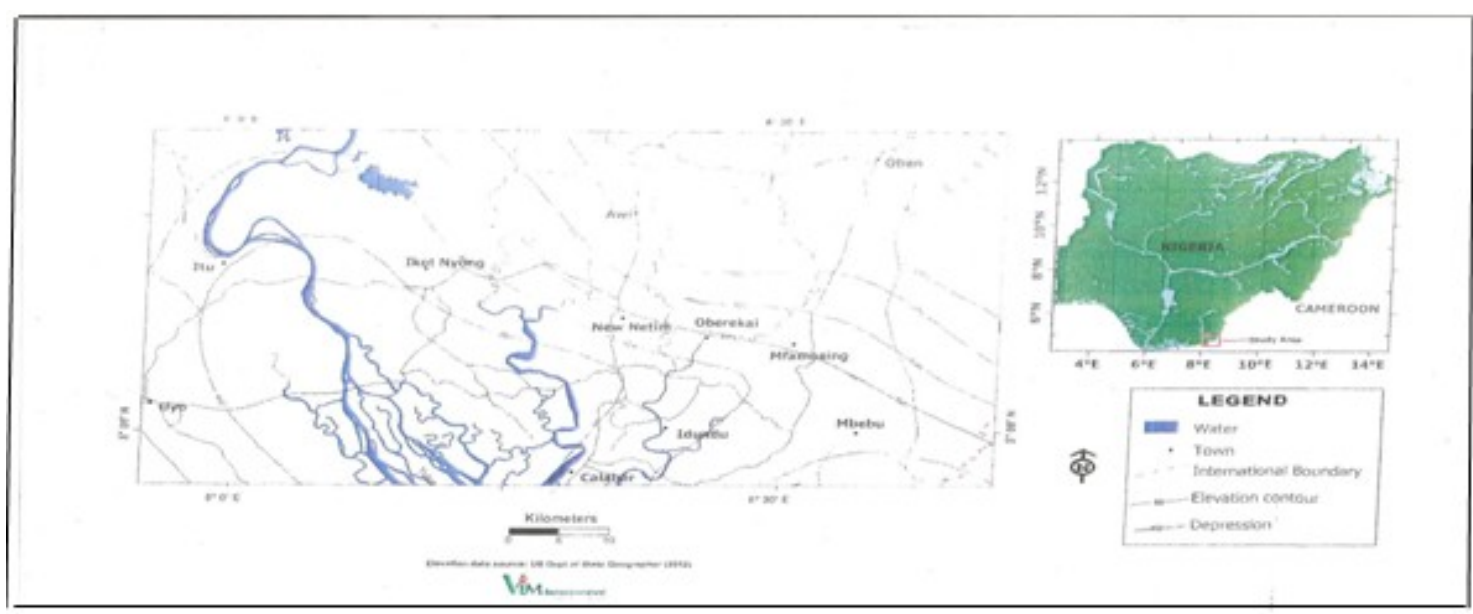

Figure 1a: Topographical Map of Part of the Calabar Flank 


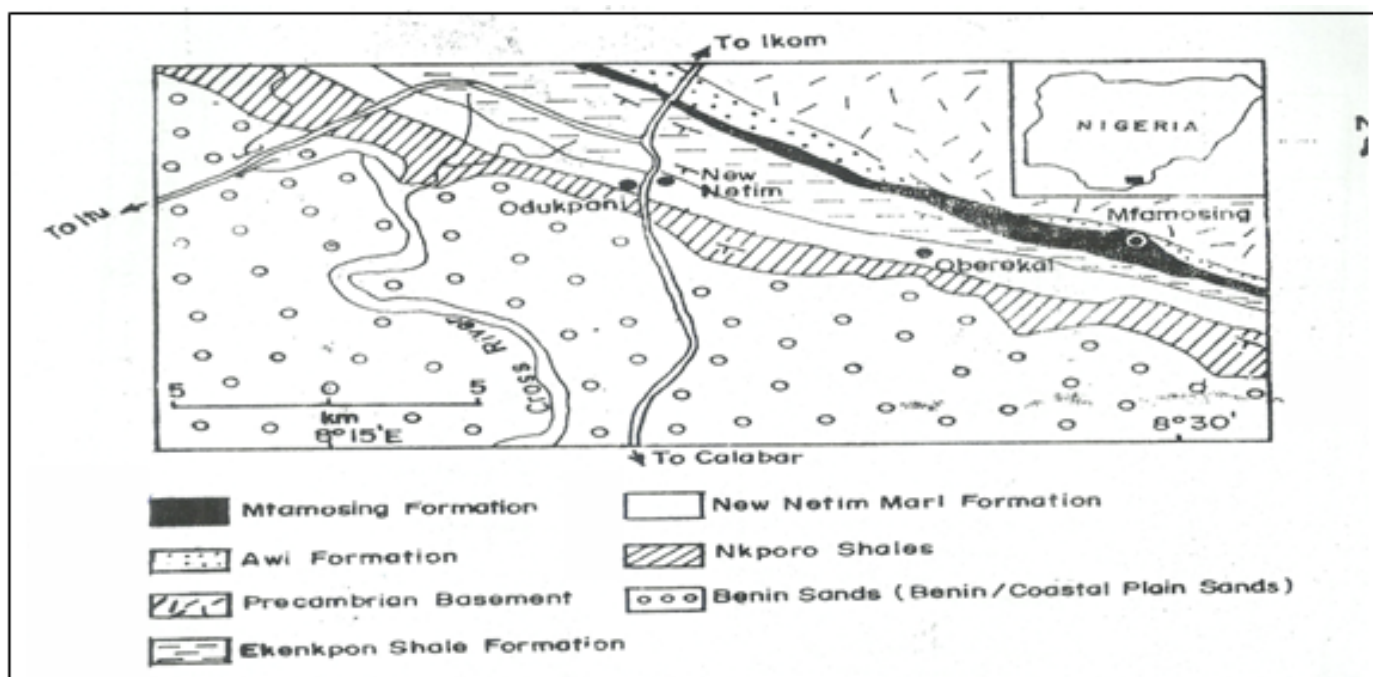

Figure 1b: Geologic sketch map of part of calabar flank, showing distribution of major lithologic units

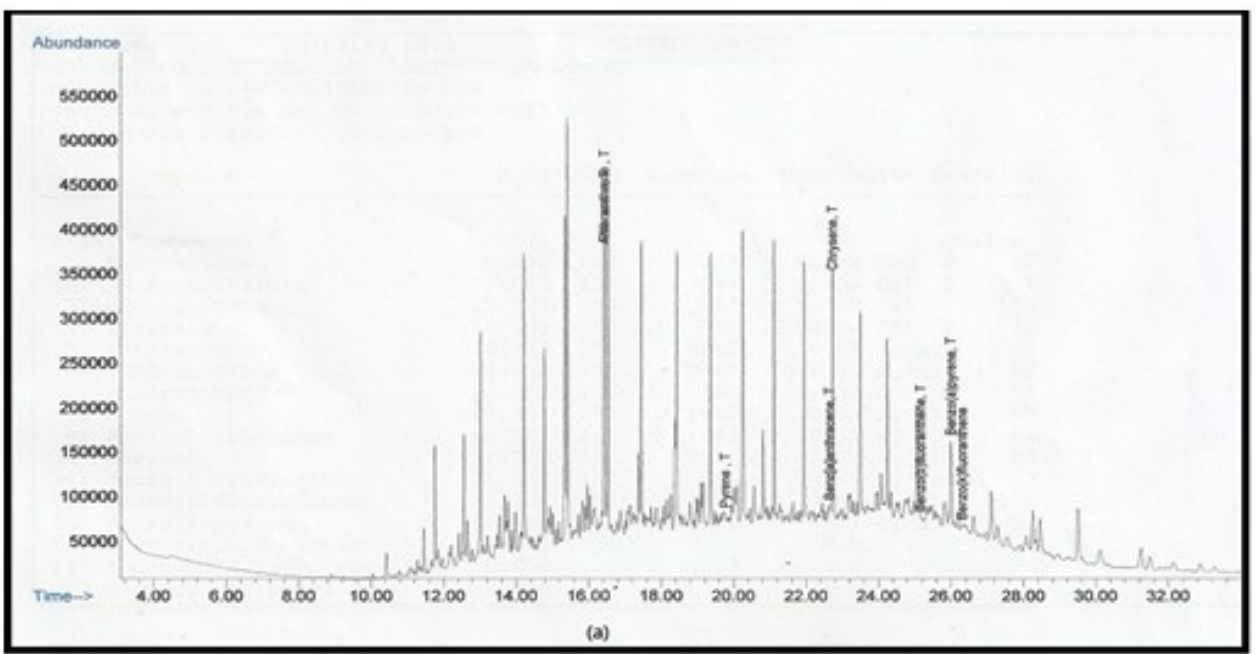

Figure 2a: Representative Mass Chromatogram showing the PAH Profile of Ekenkpon Shale

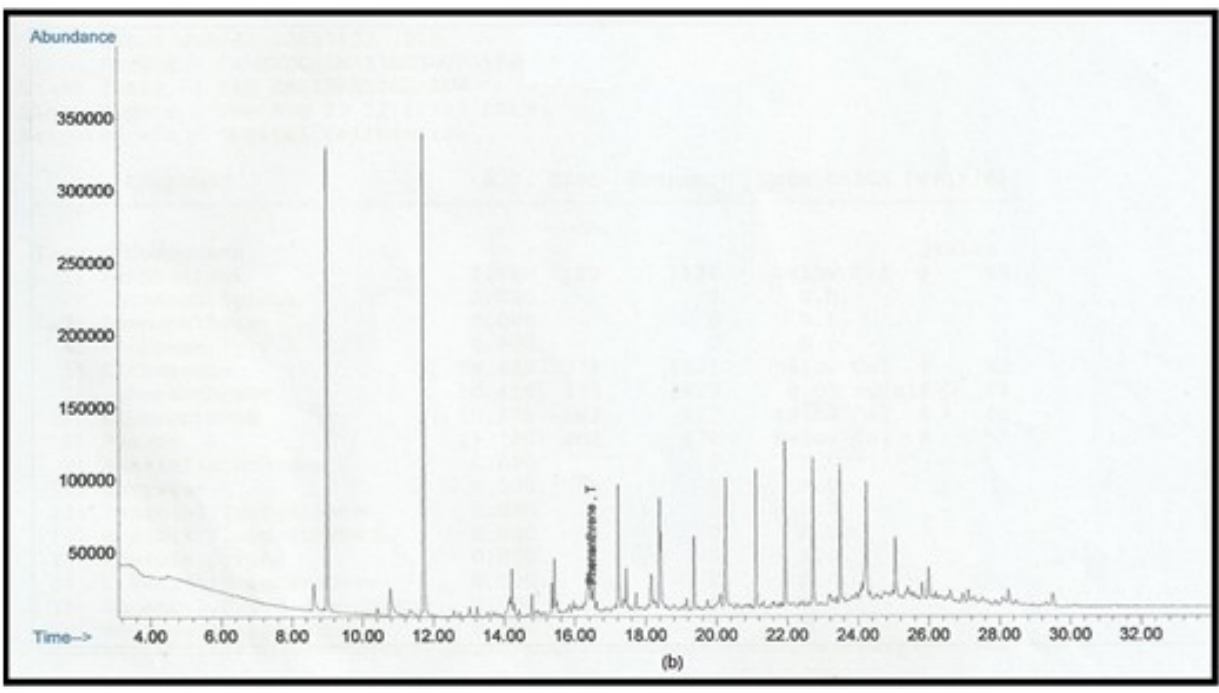

Figure 2b: Representative Mass Chromatogram showing the PAH profile of New Netim Marl 


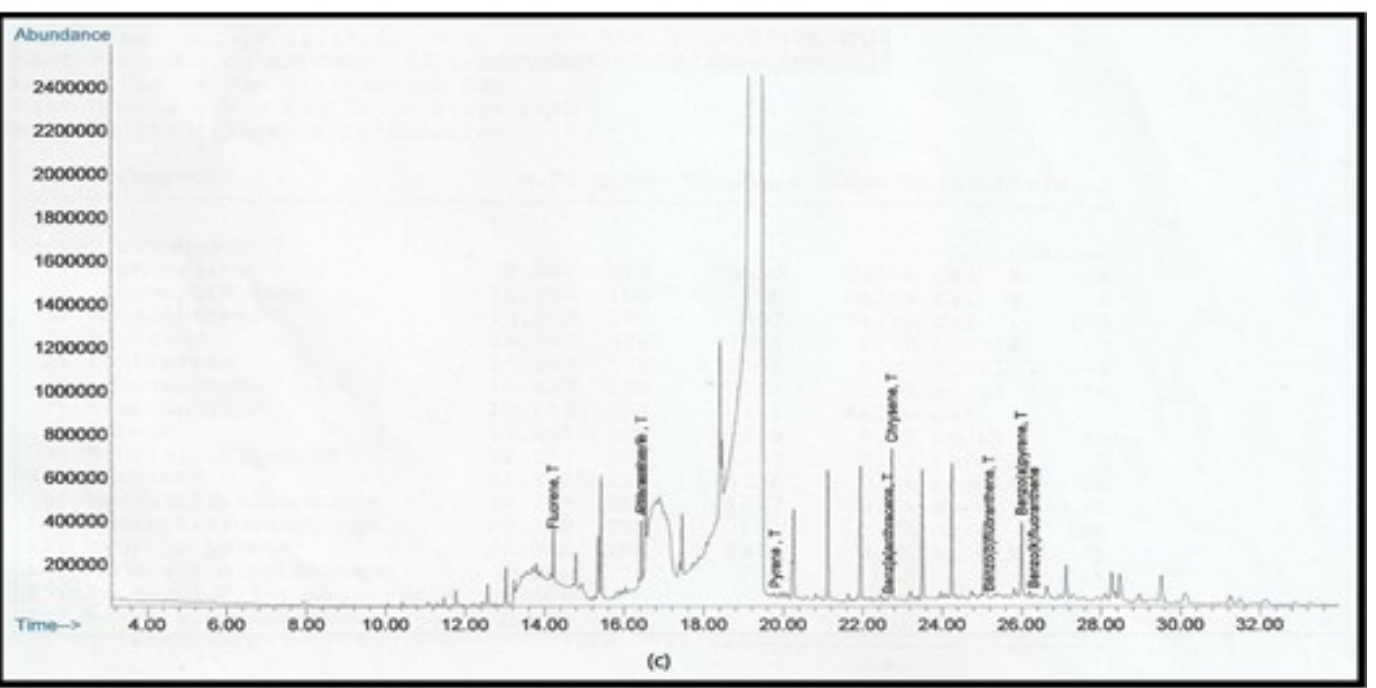

Figure 2c: Representative Mass Chromatogram showing the PAH Profile of Nkporo Shale

Table 1: Lithostratigraphic succession in the Calabar Flank correlated with Anambra Basin (Modified version alter Nyong, 1995)

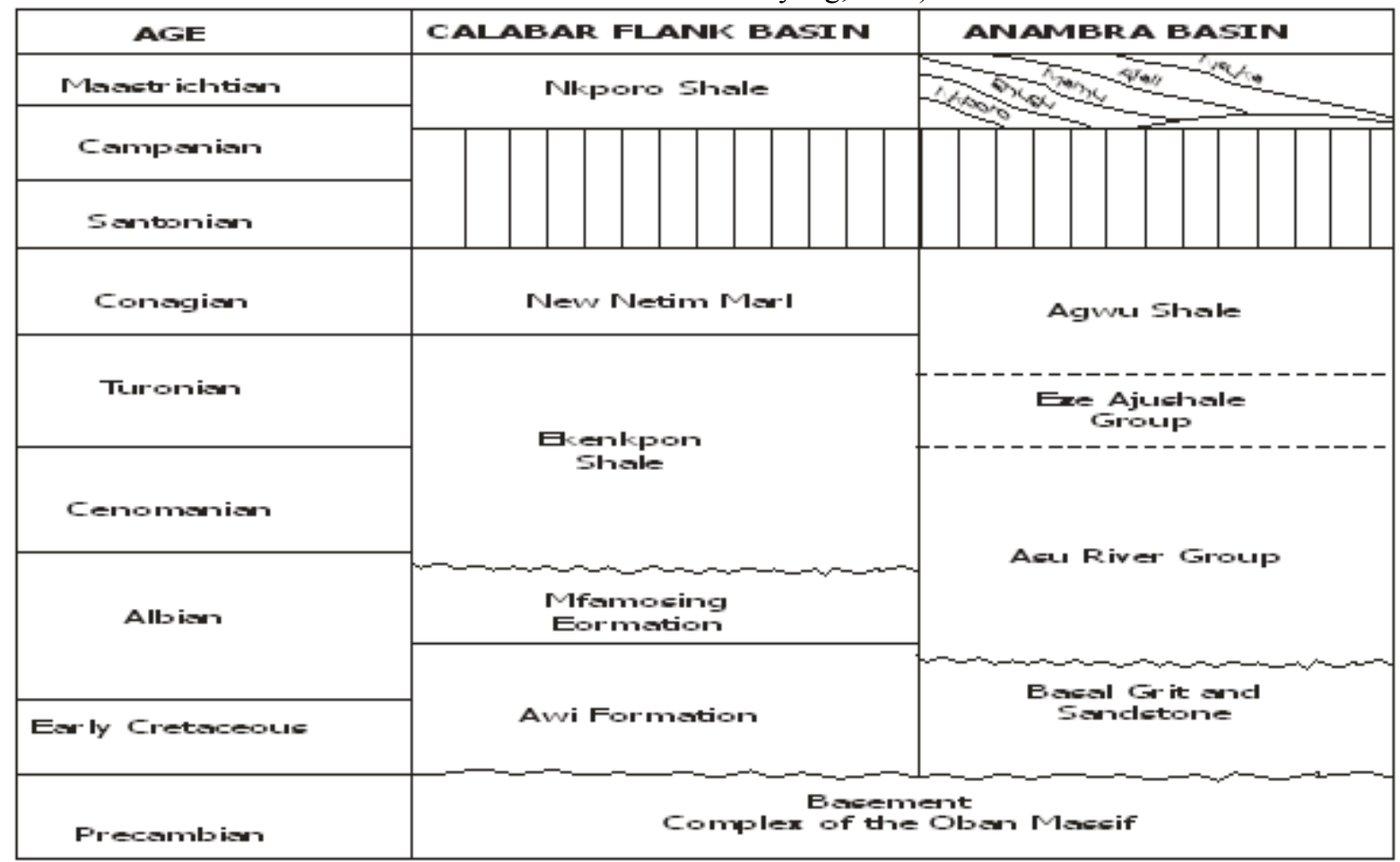


Geochemical Evaluation of Thermal Maturity of the Cretaceous Sediments in the Calabar ....

Table 2: Lithostratigraphic Succession in the Calabar Flank by various Worker

\begin{tabular}{|c|c|c|c|c|}
\hline AGE & $\begin{array}{c}\text { REYMENT, } \\
196.5\end{array}$ & $\begin{array}{l}\text { PETERS AND } \\
\text { EKEWOZOR, 1982 }\end{array}$ & $\begin{array}{c}\text { PETERS ETAL } \\
1995\end{array}$ & LI THOLOGIC DESCRIPTION \\
\hline $\begin{array}{l}\text { MAASIRI- } \\
\text { CHTIAN }\end{array}$ & $\begin{array}{l}\text { NKPORO } \\
\text { SHALES }\end{array}$ & $\begin{array}{l}\text { NKPORO } \\
\text { SHALES }\end{array}$ & $\begin{array}{l}\text { NKPORO } \\
\text { SHALES }\end{array}$ & $\begin{array}{l}\text { GYPNIFEROUS DARK } \\
\text { GRAY MITH MUCSTONE } \\
\text { INTER CALATION }\end{array}$ \\
\hline $\begin{array}{l}\text { CAMP3A- } \\
\text { NIAN } \\
\text { SANTO- } \\
\text { NIIAN }\end{array}$ & & & 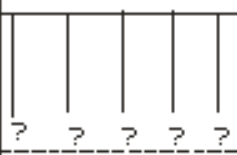 & $\begin{array}{c}\text { UNOONFORMITY } \\
\text { (NON-CEPOSITION)/OR } \\
\text { EROSION }\end{array}$ \\
\hline CONIIAN & & & $\begin{array}{l}\text { NEW NETIM } \\
\text { MARL }\end{array}$ & $\begin{array}{c}\text { MARLSTONEW ITH SHALE } \\
\text { IN TER CALATION OFMUDS TONE } \\
\text { SANDS TONE LIMESTONES } \\
\text { ANDOYS TER BEDS } \\
\end{array}$ \\
\hline TURONIAN & $\begin{array}{l}\text { EZE AKU } \\
\text { FORMATION }\end{array}$ & \multirow{2}{*}{$\begin{array}{l}\text { NKALAGU } \\
\text { FORMATION }\end{array}$} & \multirow{2}{*}{$\begin{array}{l}\text { EKENKPON } \\
\text { SHALES }\end{array}$} & $\begin{array}{c}\text { THIOK BLACK PYTRIC } \\
\text { ヨHALES WITH } \\
\text { INTERCALATION OF } \\
\text { MUSDSTONE, SANDSTONE, }\end{array}$ \\
\hline $\begin{array}{l}\text { CENO- } \\
\text { MANIAN }\end{array}$ & \multirow{3}{*}{$\begin{array}{l}\text { OCLKPANI } \\
\text { FORMATION }\end{array}$} & & & $\begin{array}{l}\text { LIMESTONE AND OYSIER } \\
\text { BEDS }\end{array}$ \\
\hline ALBIAN & & $\begin{array}{l}\text { MFAMOGNG } \\
\text { LIMESTONE }\end{array}$ & $\begin{array}{l}\text { MFAMOGNG } \\
\text { LMESTONE }\end{array}$ & $\begin{array}{l}\text { STROMALQLITIC AND } \\
\text { FISSILLIFEROUS } \\
\text { LIMESTONE }\end{array}$ \\
\hline PAFTIAN & & $\begin{array}{c}\text { AMM } \\
\text { FORMATION }\end{array}$ & $\begin{array}{l}\text { AMA } \\
\text { FORMATION }\end{array}$ & $\begin{array}{l}\text { ARKOGC SANDSTONE } \\
\text { INTERBEDCED WITH } \\
\text { SHALES }\end{array}$ \\
\hline $\begin{array}{l}\text { PRECAM- } \\
\text { BIAN }\end{array}$ & $\begin{array}{l}\text { OBAN } \\
\text { BASEMENT } \\
\text { OOMPLEX }\end{array}$ & $\begin{array}{l}\text { QBAN } \\
\text { BAGMENT } \\
\text { COMPLEX }\end{array}$ & $\begin{array}{l}\text { OBAN } \\
\text { BAEMENT } \\
\text { COMPLEX }\end{array}$ & $\begin{array}{c}\text { CRYSTAUINE BASEMENT } \\
\text { ROCKS }\end{array}$ \\
\hline
\end{tabular}

\section{Conclusion}

From the above results it can be deduced that the PAH formation and distribution in the Cretaceous sediments of the Calabar Flank is not only influenced by the burial history of the sediments, otherwise Nkporo shale, the youngest lithologic unit in the stratigraphic succession of the basin would have been the most deficient in polynuclear aromatics. Consequently, the PAH distribution pattern suggests that there could be interplay of other factors such as the quality of biogenic input - that is how rich the organic matter is in polycycloalkanes at the onset of diagenesis. Another possible influence on the PAH profile in the sediments is the palaeoenvironmental conditions favorable for the preservation of PAH precursors during diagenetic transformation of organic matter. [15] noted that the transformation of polycycloalkanes to steroidal products such as polycyclic aromatics is a common phenomenon in anoxic diagenesis and catagensis. Hence the concentration of PAHs in the sediment may also be used as a palaeoenvironmental indicator. Finally, the thermally and otherwise mediated molecular transformation of the thermodynamically less stable geofossils (biomarkers) to more stable ones may be used to evaluate the maturation level of organic matter in the sediment.

\section{References}

[1] Murat, R. C. 1972, Stratigraphy and Paleogeography of the Cretaceous Lower Tertiary and Southern Nigeria. In T. f. J. Dessauragie and A. J. Whiteman (eds). African Geology, Department of Geology. University of Ibadan Press, pp 215 - 226.

[2] Reijers, T. J. A., 1996, Selected Chapters on Geology-sedimentary Geology and Sequence Stratigraphy in Nigeria. SPDC Course Handbook (Field Guide) 121p.

[3] Reijers, T. J. A. and Petters. S. W. 1987. Depositional Environments and Diagenesis of Albian Carhonate on the Calabar Flank, S. E. Nigeria Petroleum Geology, 10(3), pp $283-291$.

[4] Ebong, U. E., 1989, The Sedimentology of the Cretaceous highway transect from the Calabar Flank across the Mamfe Embarment. Unpublished M.Sc. Thesis, University of Calabar.

[5] Unomah, G. I. and Ekweozor, C. M. 1993. Petroleum Source Rock Assessment of the Campanian Nkporo Shale, Lower Benue Trough, Nigeria. NAPE BULL. 5p. $172-186$.

[6] Kumaran, K. P. N. and Ramanathan, R. M. 1986. An Upper Cretaceous Assemblage from Nkporo Shale of Calabar Flank. Journal of the Paleontological Society of India, 31, p 9-15.

[7] Nyong, F. E. and Ramanathan, R. M, 1985. A record of oxygen deficient Paleoenvironments in the Cretaceous of the Calabar flanks, S. F. Nigeria Journal of African Earth Sciences, Vol.3(4), pp 455 - 460.

[8] Ramanathan, R. M. and Fayose, F. A., 1990. Cretaceous transgressions and regression in Calabar Flank, S. E. Nigeria. In C. O. Ofoegbe (ed) the Benue trough structure and evolution Friedr. Viewg and Sohn.

[9] Kennedy, W. Q, 1965. The influence of Basement Structure on the Evolution of the Coastal (Mesozoic and Tertiary) Basin of Africa. In SaltBasin around Africa pp.7-16.

[10] Stonely E., 1966. The Niger Delta region in the Light of theory of continental drift. Geol. Mag. 103, (5), pp. 385 - 397.

[11] Nyong, E. E. 1995. Cretaceous Sediments in the Calabar Flank. In B. N. Ekwueme, E. E. Nyong and S. W. Petters, (eds), Geological Excursion Guidebook to Oban, Calabar Flank and Mamfe Embayment, Southeastern Nigeria. Published in 
commemotation of the Nigerian Mining and Geoscience Society. $\quad 31$ st Annual Conference Calabar. March 12 - 16 Dec., Ford Publishing pp. $14-25$.

[12] Petters,S.W., Nyomg, E.E., Akpan, E.B.,Essien, N.U. 1995. Lithostratigraphic Revision of the Calabar Flank S.E. Nigeria. In Procedure of the $31^{\text {st }}$ Annual Conference of NMGS ,Calabar

[13] Adeleye, D. R. and Fayose. F. A. 1978, Stratigraphy of the types Section of Awi Formation, Odukkpani Area. Southern Nigeria Journal of Mining and Geology 15: $33-37$.

[14] Reijers, T. J. A., 1998, The Mfamosung Limestone in SE Nigeria: Outcrop Sub-surface Correlation and reservoir development. Journal of Petroleum Geology, 21, no.4, $467-482$.

[15] Killops, S. and Killops, V., Introduction to Organic Geochemistry,2 ${ }^{\text {nd }}$ ed.Blackwell Publishing Ltd,U.S.A.pp $186-187$. 